\title{
New Aspect on Di- $\mu$-[bis(diphenylphosphino)methane]dichlorotrigold(I) Chloride, Including Its Crystal and Molecular Structure
}

\author{
Ivan J. B. Lin, ", J. M. Hwang, ${ }^{\dagger}$ Da-Fa Feng, ${ }^{\dagger}$ M. C. Cheng, ${ }^{\ddagger}$ and Yu Wang ${ }^{*,}$ \\ Department of Chemistry, Fu Jen Catholic University, Hsinchuang, Taipei, 242, Taiwan, and \\ Department of Chemistry, National Taiwan University, Taipei, 107, Taiwan
}

Received October 6, $1993^{\circ}$

\begin{abstract}
The reaction of $\mathrm{HAuCl}_{4} \cdot 4 \mathrm{H}_{2} \mathrm{O}$ with dppm $\left(\mathrm{PPh}_{2} \mathrm{CH}_{2} \mathrm{PPh}_{2}\right)$ in ethanol produces $\left[\mathrm{Au}_{3}(\mathrm{dppm})_{2} \mathrm{Cl}_{2}\right] \mathrm{Cl}, 3$. This compound equilibrates with $\mathrm{Au}_{2}(\mathrm{dppm}) \mathrm{Cl}_{2}, 1$, and $\mathrm{Au}_{2}(\mathrm{dppm})_{2} \mathrm{Cl}_{2}, 2$, in solution. ${ }^{31} \mathrm{P} \mathrm{NMR}$ studies at various temperatures suggest that the exchange rate between compounds 1 and 3 is faster than that between compounds 2 and 3 . The free chloride anion in 3 is responsible for these exchanges. The strong emission of 3 in solid is attributed to the short Au...Au distances. Crystal structure data for compound 3-EtOH: space group $C 2 / c$, with $a=14.184(3) \AA$, $b=18.556(6) \AA, c=20.597(6) \AA, \beta=97.56(2)^{\circ}, Z=4$, and $V=5285(3) \AA^{3}$.
\end{abstract}

In the past few years we have been interested in the use of the phase-transfer catalysis technique to prepare ylide complexes ${ }^{1}$ of palladium, platinum, and gold. In the course of our work, we chose $\mathrm{Au}_{2}(\mathrm{dppm}) \mathrm{Cl}_{2}\left(\mathrm{dppm}=\mathrm{Ph}_{2} \mathrm{PCH}_{2} \mathrm{PPh}_{2}\right), 1$, as one of our starting materials. ${ }^{1 \mathrm{~b}}$ This common starting material, reported back in 1977 by Schmidbaur, ${ }^{2}$ was prepared by the reaction of " $\mathrm{AuCl}_{3}$ " with dppm in refluxing EtOH. In an attempt to prepare compound 1 by the reaction of $\mathrm{HAuCl}_{4} \cdot 4 \mathrm{H}_{2} \mathrm{O}$ with dppm at room temperature, we have been able to identify and isolate at least three different $\mathrm{Au}(\mathrm{I})$-dppm compounds, depending on the reaction conditions. Besides compound 1, we have isolated the dinuclear gold compound $\mathrm{Au}_{2}$ (dppm) ${ }_{2} \mathrm{Cl}_{2}, 2$, which was also reported by Schmidbaur ${ }^{3}$ by the reaction of compound 1 with dppm. The luminescent property of compound 2 has recently attracted considerable interest. ${ }^{4}$ Another $\mathrm{Au}(\mathrm{I})-\mathrm{dppm}$ complex, a trinuclear gold compound which has the formulation $\left[\mathrm{Au}_{3}(\mathrm{dppm})_{2-}\right.$ $\left.\mathrm{Cl}_{2}\right] \mathrm{Cl}, 3$, was also obtained. A similar trinuclear gold compound $\left[\mathrm{Au}_{3}(\mathrm{dppm})_{2} \mathrm{Cl}_{2}\right] \mathrm{X}\left(\mathrm{X}=\mathrm{ClO}_{4}, \mathrm{Au}\left(\mathrm{C}_{6} \mathrm{~F}_{5}\right)_{3} \mathrm{Cl}\right)$, was reported by Uson ${ }^{5}$ in 1983. Although 3 and Uson's compound have identical cations, the difference in anions causes very large differences in their chemical properties. While Uson's trinuclear gold compound is stable both as a solid and in solution, compound $\mathbf{3}$ is not. Once dissolved in solution compound 3 equilibrates with compound 1 and 2 very quickly. In this paper we wish to report our interesting discoveries related to these $\mathrm{Au}-\mathrm{dppm}$ compounds.

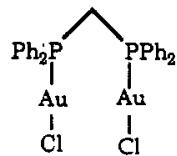

1

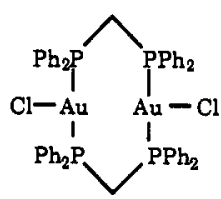

2

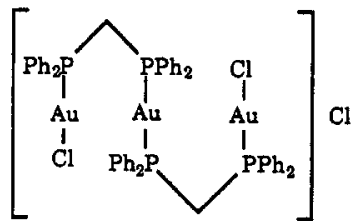

3

\section{Results and Discussion}

Synthesis and Characterization. Schmidbaur ${ }^{2}$ reported the synthesis of the colorless compound 1 in $51 \%$ yield by refluxing

$\uparrow$ Fu Jen Catholic University.

I National Taiwan University.

- Abstract published in Advance ACS Abstracts, July 1, 1994

(1) (a) Lin, I. J. B.; Shen, H. I. J. Chin. Chem. Soc. 1992, 39, 583. (b) Lin, 1. J. B.; Liu, C. W.; Liu, L.-K.; Wen, Y.-S. Organometallics 1992, 11, 1447. (c) Lai, J. S.; Wu, R. F.; Lin, I. J. B.; Cheng, M. C.; Wang, Y. J. Organomet. Chem. 1990, 393, 431. (d) Wu, R. F.; Lin, I. J. B.; Lee G. H.; Cheng, M. C.; Wang, Y. Organometallics 1990, 9, 126.

(2) Schmidbaur, H.; Wohlleben, A.; Wagner, F.; Orama O.; Huttner, G. Chem. Ber, 1977, 110, 1748 .
" $\mathrm{AuCl}_{3}$ " with dppm (1:1 molar ratio) in EtOH. In our work, compound 1 is obtained in $93 \%$ yield by the reaction of $\mathrm{HAuCl}_{4} \cdot 4 \mathrm{H}_{2} \mathrm{O}$ with dppm at room temperature in a mixture of EtOH $/ \mathrm{CH}_{2} \mathrm{Cl}_{2} / \mathrm{CHCl}_{3}$ (1:1:1 by volume). Such a solvent combination is necessary to synthesize 1 in good yield. A ternary solvent system $\left(\mathrm{EtOH} / \mathrm{CHCl}_{3} /\left(\mathrm{CH}_{3}\right)_{2} \mathrm{CO}\right)$ has also been used for the synthesis of $\mathrm{Au}\left(\mathrm{PPh}_{3}\right) \mathrm{Cl} .{ }^{6}$ Alternatively reduction of $\mathrm{Au}$ (III) to $\mathrm{Au}(\mathrm{I})$ by the reaction of $\mathrm{HAuCl}_{4} \cdot 4 \mathrm{H}_{2} \mathrm{O}$ with $2,2^{\prime}$ thiodiethanol (thiodiglycol, $\left.\left(\mathrm{HOCH}_{2} \mathrm{CH}_{2}\right)_{2} \mathrm{~S}\right)$ followed by the reaction with a 0.5 molar ratio of dppm produces 1 in $85 \%$ yield. Although 1 is stable in most solvents, it decomposes in DMSO after 1 day. ${ }^{31} \mathrm{P}$ NMR spectroscopy study suggests the formation of a tetranuclear gold compound, $\mathrm{Au}_{4}(\mathrm{dppm})(\mathrm{dppm}-\mathrm{H}) \mathrm{Cl}_{3}$, which has been prepared by a different route and will be published elsewhere.

Preparation of 2 was reported by Schmidbaur et $a l^{3}$ in $92 \%$ yield by the reaction of 1 with dppm. When $\mathrm{HAuCl}_{4} \cdot 4 \mathrm{H}_{2} \mathrm{O}$ simply reacts with a 1.5 molar ratio of dppm in an $\mathrm{EtOH} / \mathrm{CH}_{2} \mathrm{Cl}_{2}$ / $\mathrm{CHCl}_{3}$ solvent system, we are able to obtain 2 in $80 \%$ yield after recrystallization. In many cases, we isolated a species $\mathrm{Au}_{2}(\mathrm{dppm})_{3^{-}}$ $\mathrm{Cl}_{2},{ }^{7}$ which upon dissolving in solvent was difficult to recover. ${ }^{31 \mathrm{P}}$ NMR spectrum of this compound in $\mathrm{CDCl}_{3}$ shows two broad signals assignable to compound 2 and dppm. Attempts to recrystallize this compound give compound 2 .

Synthesis of compound $\mathbf{3}$ is achieved simply by dissolving $\mathrm{HAuCl}_{4} \cdot 4 \mathrm{H}_{2} \mathrm{O}$ in a vast quantity of EtOH in the presence of a 1.2 molar ratio of dppm. Large crystals of 3 are obtained in $61 \%$ yield after recrystallization from ethylacetate or acetone. Alternatively, 3 is obtained in $60 \%$ yield by reacting $\mathrm{HAuCl}_{4} \cdot 4 \mathrm{H}_{2} \mathrm{O}$ with $2,2^{\prime}$ - thiodiethanol in EtOH before treating it with dppm. Uson's trinuclear gold-dppm compound was prepared either by the reaction of $\mathrm{Au}_{2}(\mathrm{dppm})_{2} \mathrm{Cl}_{2}$ with $\mathrm{Tl}\left(\mathrm{C}_{6} \mathrm{~F}_{5}\right)_{2} \mathrm{Cl}$ or from the

(3) Schmidbaur, H.; Wohlleben, A.; Schubert, U.; Frank, A.; Hutter, G. Chem. Ber. 1977, 110, 2751.

(4) (a) Khan, M. N. I.; King, C.; Heinrich, D. D.; Fackler, J. P., Jr.; Porter, L. C. Inorg. Chem. 1989, 28, 2150. (b) King, C.; Wang, J. C.; Khan, M. N. I.; Fackler, J. P., Jr. Inorg. Chem. 1989, 28, 2145. (c) Che, C. -M.; Kwong, H. -L.; Yam, V. W.-W.; Cho, K.-C. J. Chem. Soc., Chem. Commun. 1989, 885. (d) Che, C.-M.; Kwong, H.-L.; Poon, C.-K.; Yam, v. W.-W. J. Chem. Soc., Dalton Trans. 1990, 3215.

(5) Uson, R.; Laguna, A.; Femandez, E.; Villacampa, M.; Jones, P. G.; Sheldrick, G. M. J. Chem. Soc., Dalton Trans. 1983, 1679.

(6) McAuliffe, C. A.; Parish, R. V.; Randall, P. D. J. Chem. Soc., Dalton Trans. 1979, 1730.

(7) Anal. Calcd for $\mathrm{C}_{75} \mathrm{H}_{36} \mathrm{Cl}_{2} \mathrm{P}_{6} \mathrm{Au}_{2}: \mathrm{C}, 53.4 ; \mathrm{H}, 4.1$. Found: $\mathrm{C}, 53.3 ; \mathrm{H}$, 4.6. The analogous bromo compound was reported: Al-Baker, S.; Hill, W. E.; McAuliffe, C. A. J. Chem. Soc., Dalton Trans. 1985, 2655. The observation of 2 and free dppm in $31 \mathrm{P}$ NMR spectrum while dissolving $\mathrm{Au}_{2}$ (dppm) $\mathrm{Cl}_{2}$ in $\mathrm{CDCl}_{3}$ is different from that reported by BernersPrice and Sadler. $11 \mathrm{c}$ 
Table 1. Crystal Data for $\left[\mathrm{Au}_{3}(\mathrm{dppm})_{2} \mathrm{Cl}_{2}\right] \mathrm{Cl} \cdot \mathrm{EtOH}$ and $\left[\mathrm{Au}_{3}(\mathrm{dppm})_{2} \mathrm{Cl}_{2}\right] \mathrm{Cl} \cdot \mathrm{EtOH} \cdot \mathrm{H}_{2} \mathrm{O}$

\begin{tabular}{|c|c|c|}
\hline 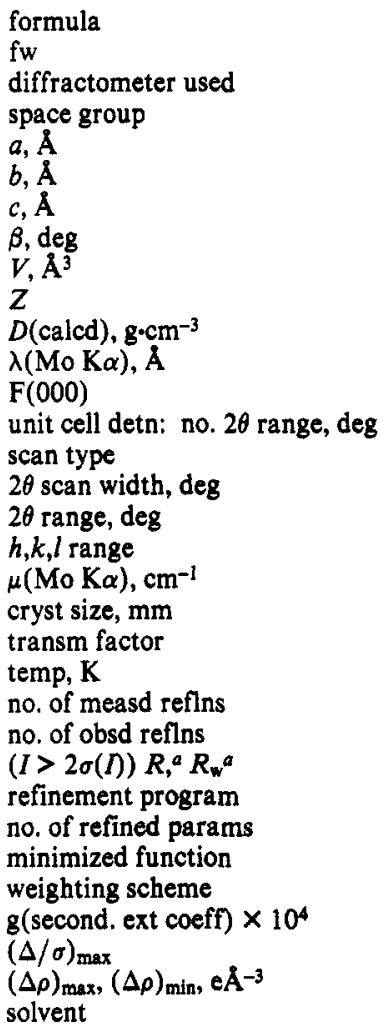 & $\begin{array}{l}\mathrm{Au}_{3} \mathrm{P}_{4} \mathrm{C}_{52} \mathrm{Cl}_{3} \mathrm{H}_{44} \mathrm{O}_{1} \\
1506.06 \\
\mathrm{CAD} 4 \\
\mathrm{C} 2 / c \\
14.184(3) \\
18.556(6) \\
20.257(6) \\
97.56(2) \\
5285(3) \\
4 \\
1.893 \\
0.71069 \\
2848 \\
25 ; 19-24 \\
\theta / \theta 2 \\
2(0.85+0.35 \text { tan } \theta) \\
2-45 \\
-15 \text { to } 15,0 \text { to } 20,0 \text { to } 21 \\
58.9 \\
0.2 \times 0.35 \times 040 \\
0.709-1.0 \\
298 \\
3622 \\
2648 \\
0.030,0.026 \\
\text { NRCVAX } \\
286 \\
w \mid F_{0}-F_{\mathrm{d}}{ }^{2} \\
1 / \sigma^{2}(\mathrm{Fo}) \\
0.46(2) \\
0.514 \\
0.84,-0.77 \\
\text { EtOH } \\
\end{array}$ & $\begin{array}{l}\mathrm{Au}_{3} \mathrm{P}_{4} \mathrm{C}_{52} \mathrm{Cl}_{3} \mathrm{H}_{46} \mathrm{O}_{2} \\
1522.06 \\
\mathrm{CAD} 4 \\
P 2_{1} / n \\
16.557(4) \\
18.886(4) \\
18.702(7) \\
113.19(3) \\
5194(3) \\
4 \\
1.946 \\
0.71069 \\
2880 \\
24 ; 18-22 \\
\theta / 2 \theta \\
2(0.75+0.35 \text { tan } \theta) \\
2-45 \\
-17 \text { to } 16,0 \text { to } 20,0 \text { to } 19 \\
87.4 \\
0.25 \times 0.30 \times 0.20 \\
0.617-1.0 \\
298 \\
6835 \\
3491 \\
0.045,0.043 \\
\mathrm{NRCVAX} \\
558 \\
w \mid F_{0}-F_{0} d^{2} \\
1 /\left[\sigma^{2}\left(F_{0}\right)+0.3 \times 10^{-4} F_{0}{ }^{2}\right] \\
0.29(3) \\
0.142 \\
1.16,-0.78 \\
\mathrm{H}_{2} \mathrm{O}, \mathrm{EtOH} \\
\end{array}$ \\
\hline
\end{tabular}

reaction of $\mathrm{Au}_{2}$ (dppm) $\mathrm{Cl}_{2}$ with $\mathrm{AgClO}_{4}$ followed by dppm then $\mathrm{AuCl}\left(\mathrm{C}_{4} \mathrm{H}_{4} \mathrm{~S}\right)$. Surprisingly, in spite of the similarity in formula between 3 and Uson's compound, 3 has never been reported. This may be due to the instability of 3 in solvent. When dissolved in $\mathrm{CHCl}_{3}$ or $\mathrm{CH}_{2} \mathrm{Cl}_{2}, 3$ is difficult to recover.

Since the characterization of 3 in solution is difficult, single crystal X-ray diffraction was performed. Two different crystals in different space groups were structurally determined. Both crystals contained a solvent molecule, EtOH. One crystal had an additional $\mathrm{H}_{2} \mathrm{O}$ molecule as solvent molecule. The crystal data are shown in Table 1 . The molecular structures of the cations are the same for both crystals. The atomic parameters of only one crystal (the one without $\mathrm{H}_{2} \mathrm{O}$ ) are given in Table 2. The molecular structure of the cation, having a $C_{2}$ symmetry, is depicted in Figure 1. Some selected bond distances and angles are given in the caption. The three gold atoms are in a $\mathrm{V}$ shape arrangement, with two short (3.076(1) $\AA$ ) and one long (3.729(1) $\AA$ ) Au...Au distances. This is compared with the two short Au...Au distances of 3.067(5) and 3.164(5) $\AA$, and the long distance of $3.676(5) \AA$ of Uson's compound. The luminescent properties of 3 may be attributed to these gold-gold interactions. The Au2-Au 1-Au2a angle $\left(74.61(3)^{\circ}\right)$ (the atom Au2a is related to Au2 by $C_{2}$ symmetry) is larger than the one in the literature $\left(72.3^{\circ}\right) .^{5}$ There is a substantial trans influence in Au2-P1 $(2.240$ $\AA$, trans to chloride) in comparison with Au1-P2 (2.319 $\AA$, trans to phosphorus). Similar results were observed in Uson's trinuclear gold compound. This trans influence may have some implications on the exchange behavior of 3 in solution and will be discussed in a later section. The two $\mathrm{P}-\mathrm{Au}-\mathrm{Cl}$ limbs are pointing toward opposite directions such that further reaction with dppm to close up the trinuclear gold is unlikely. The free chloride anion has no interaction with any of the three gold atoms $(>8 \AA)$, although interaction of the free halide with the cation is expected in solution.

Compound 3 is luminescent in the solid state. Excitation of the solid sample at 357 or $366 \mathrm{~nm}$ at room temperature results in an intense greenish blue emission with a maximum at $485 \mathrm{~nm}$ and a weak shoulder at $525 \mathrm{~nm}$ (Figure 2). Both emissions have
Table 2. Atomic Parameters $x, y, z$, and $B_{i 00}$ of $\left[\mathrm{Au}_{3}(\mathrm{dppm})_{2} \mathrm{Cl}_{2}\right] \mathrm{Cl} \cdot \mathrm{EtOH}$, where Esds Refer to the Last Digit Printed

\begin{tabular}{lllll}
\hline \multicolumn{1}{c}{$x$} & \multicolumn{1}{c}{$y$} & \multicolumn{1}{c}{$z$} & \multicolumn{1}{c}{$B_{\text {ibo }} \AA^{2}$} \\
\hline Au1 & 0 & $0.20744(3)$ & $1 / 4$ & $2.54(3)$ \\
Au2 & $0.12994(3)$ & $0.33930(3)$ & $0.280257(23)$ & $3.653(22)$ \\
P1 & $0.21188(20)$ & $0.29073(16)$ & $0.20407(14)$ & $3.10(14)$ \\
P2 & $0.04946(19)$ & $0.19499(14)$ & $0.14592(13)$ & $2.41(13)$ \\
Cl & $0.05038(24)$ & $0.39652(19)$ & $0.35649(18)$ & $6.72(20)$ \\
C & $0.1333(7)$ & $0.2647(5)$ & $0.1312(5)$ & $2.6(5)$ \\
C11A & $0.2803(7)$ & $0.2118(5)$ & $0.2302(5)$ & $3.4(5)$ \\
C12A & $0.3225(7)$ & $0.1703(6)$ & $0.1862(5)$ & $4.0(6)$ \\
C13A & $0.3712(8)$ & $0.1089(6)$ & $0.2071(6)$ & $5.3(7)$ \\
C14A & $0.3776(9)$ & $0.0888(7)$ & $0.2724(6)$ & $6.3(7)$ \\
C15A & $0.3388(9)$ & $0.1300(7)$ & $0.3169(6)$ & $6.0(8)$ \\
C16A & $0.2914(8)$ & $0.1909(6)$ & $0.2955(5)$ & $4.3(6)$ \\
C11B & $0.2916(7)$ & $0.3545(5)$ & $0.1713(5)$ & $3.3(5)$ \\
C12B & $0.2535(8)$ & $0.4164(6)$ & $0.1422(6)$ & $4.9(7)$ \\
C13B & $0.3113(10)$ & $0.4672(6)$ & $0.1165(6)$ & $6.3(8)$ \\
C14B & $0.4066(9)$ & $0.4562(7)$ & $0.1234(6)$ & $6.9(8)$ \\
C15B & $0.4456(9)$ & $0.3951(7)$ & $0.1528(8)$ & $8.7(10)$ \\
C16B & $0.3897(8)$ & $0.3439(7)$ & $0.1788(7)$ & $6.5(8)$ \\
C21A & $0.1077(7)$ & $0.1094(5)$ & $0.1394(5)$ & $2.6(5)$ \\
C22A & $0.1393(8)$ & $0.0897(6)$ & $0.0787(5)$ & $4.6(6)$ \\
C23A & $0.1843(9)$ & $0.0258(7)$ & $0.0740(6)$ & $6.1(7)$ \\
C24A & $0.1966(9)$ & $-0.0201(6)$ & $0.1298(7)$ & $6.4(7)$ \\
C25A & $0.1669(9)$ & $-0.0008(6)$ & $0.1888(5)$ & $5.0(7)$ \\
C26A & $0.1213(7)$ & $0.0635(5)$ & $0.1943(5)$ & $3.4(6)$ \\
C21B & $-0.0419(7)$ & $0.1961(5)$ & $0.0744(5)$ & $2.9(5)$ \\
C22B & $-0.1268(7)$ & $0.1607(6)$ & $0.0784(5)$ & $3.8(5)$ \\
C23B & $-0.1940(8)$ & $0.1554(6)$ & $0.0246(6)$ & $5.2(6)$ \\
C24B & $-0.1795(8)$ & $0.1862(6)$ & $-0.0337(6)$ & $5.1(6)$ \\
C25B & $-0.0960(9)$ & $0.2209(6)$ & $-0.0399(5)$ & $5.3(7)$ \\
C26B & $-0.0260(8)$ & $0.2257(6)$ & $0.0134(5)$ & $4.7(7)$ \\
Cl1 & $1 / 4$ & $1 / 4$ & 0 & $13.0(5)$ \\
O31a & $0.5978(14)$ & $0.0247(10)$ & $0.0316(10)$ & $9.3(6)$ \\
C32a & $0.5219(20)$ & $0.0221(14)$ & $0.0170(14)$ & $6.4(7)$ \\
C33a & $0.4542(16)$ & $0.0673(12)$ & $0.0213(11)$ & $4.9(6)$ \\
& & & &
\end{tabular}

${ }^{a}$ Mean atoms with occupance $=0.5$.

identical lifetimes of $11 \mu \mathrm{s}$. The luminescent properties of many gold(I) phosphine complexes have been studied. The emissive 


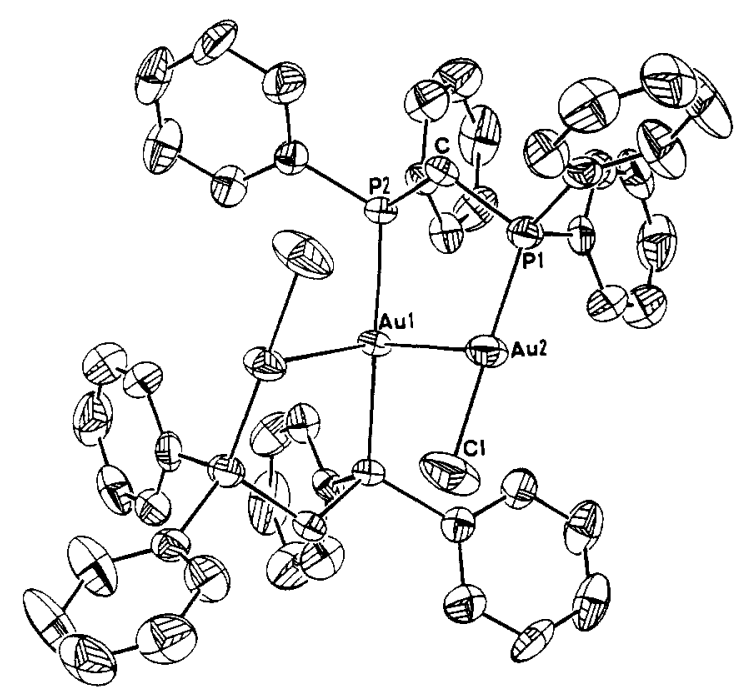

Figure 1. Molecular structure of compound 3. The thermal ellipsoids are in 50\% probability. For clarity phenyl carbons are not labeled. Complete labels can be found in the deposit material. Selected bond lengths and bond angles are as follows: Aul-Au2-3.076(1) $\AA$, Au1-P2-2.319(3) $\AA$. Au2-P1-2.240(3) $\AA$, Au2-Cl-2.290(3) A; Au2-Au1-Au2a-74.61(3) ${ }^{\circ}$, P2-Au1-P2a-168.6(1) ${ }^{\circ}$.

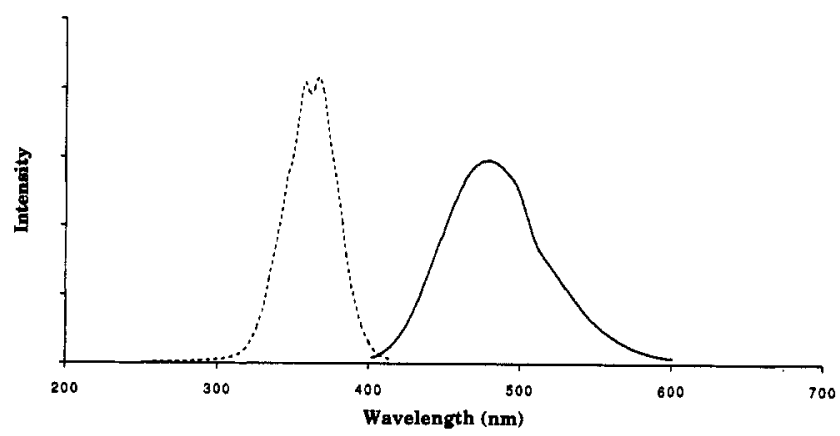

Figure 2. Solid state excitation (...) and emission (-) spectra of $\left[\mathrm{Au}_{3}(\mathrm{dppm})_{2} \mathrm{Cl}_{2}\right] \mathrm{Cl}$ at room temperature.

excited states of these compounds have been suggested to arise from the metal-centered transitions, ${ }^{46,8}$ the gold to phosphine charge-transfer transitions, ${ }^{9}$ or the metal mediated intraligand transitions. ${ }^{9 a, 10}$ Since symmetric linear bis(phosphine)gold(I) complexes are not luminous and $\mathrm{Au}\left(\mathrm{PPh}_{3}\right) \mathrm{Cl}$ only shows a slight bluish white emission due to $\pi^{*} \rightarrow \pi$ transition on the phenyl ring, the strong emission of 3 appears to arise from its gold-gold interactions. ${ }^{10 \mathrm{~b}}$ The strong luminescent property of $\left[\mathrm{Au}_{2}-\right.$ $\left.(\mathrm{dppm})_{2}\right]^{2+}$ has also been attributed to the short Au..Au distances $(<3.0 \AA)$. $3,4 a, b$ For a comparison, the emission spectrum of the dinuclear compound $\mathrm{Au}_{2}(\mathrm{dppm}) \mathrm{Cl}_{2}$ was also taken. When excited at $300 \mathrm{~nm}$, a strong emission appeared at $620 \mathrm{~nm}$ in the solid state. Again, this compound has a Au-Au distance of 3.351(2) $\AA^{2}{ }^{2}$

NMR Studies. The ${ }^{31} \mathrm{P}$ NMR spectrum of 3 in $\mathrm{CDCl}_{3}$ at 297 $\mathrm{K}$ is shown in Figure $3 \mathrm{~b}$. It has two very broad signals and a relatively sharp signal at $39.0,27.6$, and $32.6 \mathrm{ppm}$ respectively. There is no correlation between their relative intensities. The ${ }^{31} \mathrm{P}$

(8) (a) Gray, H. B.; Harvey, P. D. J. Am. Chem. Soc. 1988, 110, 2145. (b) Che, C.-M.; Yip, H.-K.; Yam, V. W.-W.; Cheung, P.-Y.; Lai, T.-F.; Shieh, S.-J.; Peng, S.-M. J. Chem. Soc., Dalton Trans. 1992, 427. (c) Yam, V. W.-W.; L Lee, W.-K. J. Chem. Soc., Dalton Trans. 1993, 2097.

(9) (a) Ziolo, R. F.; Lipton, S.; Dori, Z. J. Chem. Soc., Chem. Commun. 1970, 1124. (b) Vogler, A.; Kunkely, H. Chem. Phys. Lett. 1988, 150 135.

(10) (a) Segers, D. P.; DeArmond, M. K.; Grutsch, P. A.; Kutal, C. Inorg. Chem. 1984, 23, 2874. (b) King. C.; Khan, M. N. I.; Staples, R. J.; Fackler, J. P., Jr. Inorg. Chem. 1992, 31, 3236. (c) Shieh, S. J.; Li, D. Peng, S.-M.; Che, C.-M. J. Chem. Soc., Dalton Trans. 1993, 195. (d) Tzeng, B.-C.; Li, D.; Peng, S.-M.; Che, C.-M. J. Chem. Soc., Dalton Trans. 1993, 2365.

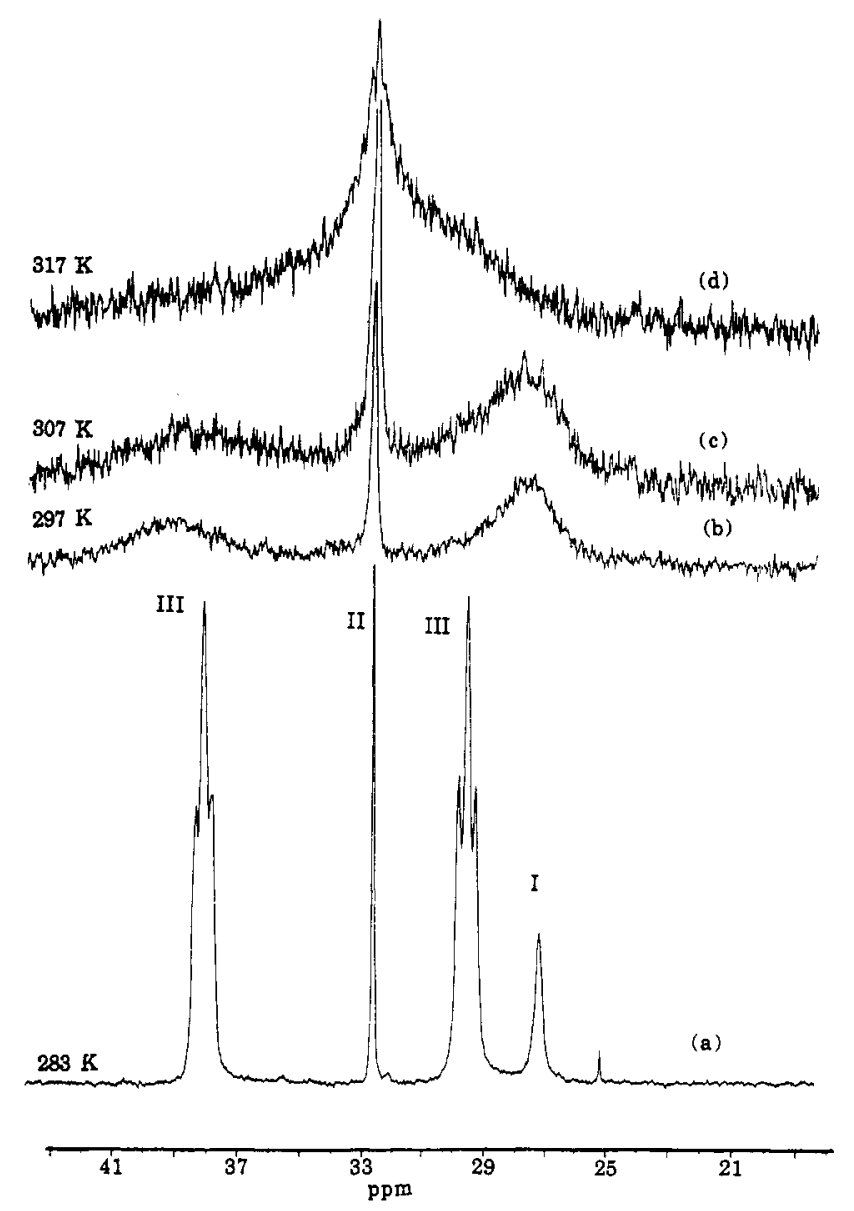

Figure 3. ${ }^{31} \mathrm{P}\left\{{ }^{1} \mathrm{H}\right\} \mathrm{NMR}$ spectra of compound 3 in $\mathrm{CDCl}_{3}$ at (a) $283 \mathrm{~K}$, (b) $297 \mathrm{~K}$, (c) $307 \mathrm{~K}$, and (d) $317 \mathrm{~K}$.

NMR spectrum of 3 at $297 \mathrm{~K}$ in DMSO- $d_{6}$ is also shown in Figure 4a. The two smaller broad signals at 40.2 and $34.5 \mathrm{ppm}$ are of equal intensity, and the two large sharper signals at 37.4 and $31.4 \mathrm{ppm}$ are also of equal intensity. Low-temperature spectra in $\mathrm{CDCl}_{3}$ were taken. At $283 \mathrm{~K}$ (Figure 3a) a set of $\mathrm{AA}^{\prime} \mathbf{B B}^{\prime}$ pattern (signal III) appears at 38.0 and $29.5 \mathrm{ppm}\left(J\left(\mathrm{AA}^{\prime}\right)\right.$ $\left.=309, J(\mathrm{AB})=4.8, J\left(\mathrm{BB}^{\prime}\right)=-0.2, J\left(\mathrm{AB}^{\prime}\right)=-1.9 \mathrm{~Hz}\right)$, together with two singlets at $32.6 \mathrm{ppm}$ (signal II) and $27.2 \mathrm{ppm}$ (signal I). The relative intensity of signal I to II is 1 to 1 , but there is no correlation between the intensities of signal III and II (or I). Increasing the temperature to $297 \mathrm{~K}$ (Figure 3b), signals I and III begin to merge while signal II remains relatively sharp. At $307 \mathrm{~K}$, all signals become broader. When the temperature is further increased to $317 \mathrm{~K}$, the signals all merge to a broad band. Variable temperature spectra of 3 in DMSO- $d_{6}$ in the high temperature range are shown in Figure 4. Signals I and III begin to merge at $\sim 307 \mathrm{~K}$, and all signals merge to a broad signal only at $357 \mathrm{~K}$.

Apparently, in both solvents, there are two different stages of line broadening, and the exchange rate between signal I and III is faster than that of II and III. It is also interesting to note that the exchange rates among signals $I, I I$, and III in DMSO- $d_{6}$ are slower than those in $\mathrm{CDCl}_{3}$ at the same temperature. In both solvents, the relative intensities of signals I, II, and III are different at different temperatures. Signal I is assigned to compound $\mathbf{1}$, signal II to compound 2, and signal III to compound 3. The assignments of signals I, II, and III are done in the following manner.

When a 1:1.20 molar ratio of $\mathrm{AgBF}_{4}$ in proportions is added to a freshly prepared $\mathrm{CDCl}_{3}$ solution of 3 , the ${ }^{31} \mathrm{P}$ NMR spectrum changes dramatically (Figure 5). The broad signals become sharp gradually and eventually show a sharp $\mathbf{A A}^{\prime} \mathbf{B B}^{\prime}$ pattern (at 37.1 and $29.0 \mathrm{ppm}$ ), very close to that of $\left[\mathrm{Au}_{3}(\mathrm{dppm})_{2} \mathrm{Cl}_{2}\right] \mathrm{X}$ reported 


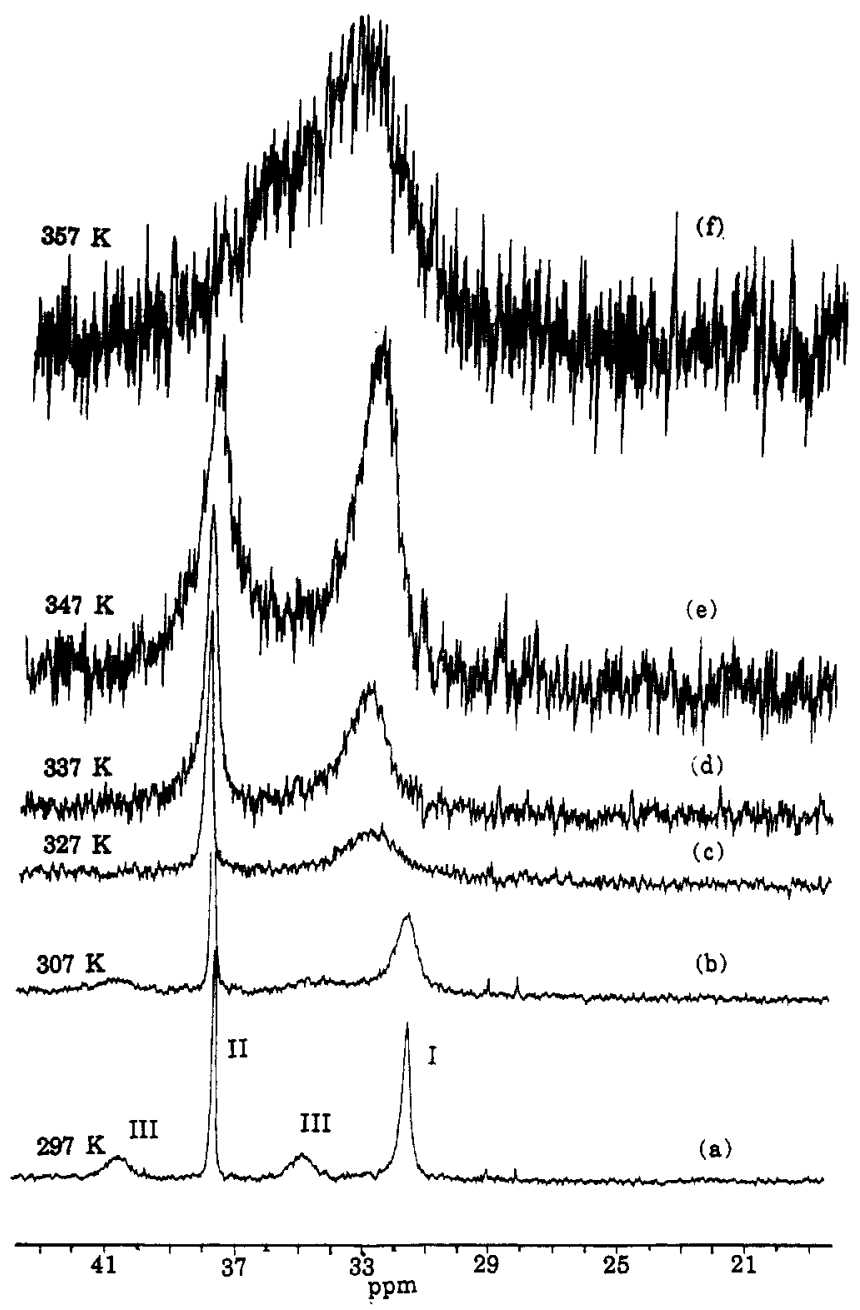

Figure 4. ${ }^{31} \mathrm{P}\left\{{ }^{1} \mathrm{H}\right\}$ NMR spectra of compound 3 in DMSO- $d_{6}$ at (a) 297 $\mathrm{K}$, (b) $307 \mathrm{~K}$, (c) $327 \mathrm{~K}$, (d) $337 \mathrm{~K}$, (e) $347 \mathrm{~K}$, and (f) $357 \mathrm{~K}$.

by Uson (36.6 and $29.0 \mathrm{ppm}$ ). ${ }^{5}$ At the same time, signal II gradually decreases in intensity and the chemical shift moves downfield from 32.6 to $35.6 \mathrm{ppm}$. The addition of $\left[\mathrm{Au}_{3}(\mathrm{dppm})_{2-}\right.$ $\left.\mathrm{Cl}_{2}\right]\left(\mathrm{ClO}_{4}\right)$ to the solution does not generate any new signal, but the intensity of signal III increases. The addition of $(n-\mathrm{Bu})_{4} \mathrm{NCl}$ to the above solution, broadens the signals and moves the chemical shift of signal II from $35.6 \mathrm{ppm}$ back to $32.6 \mathrm{ppm}$ again and the intensity increases. These processes are reversible. Therefore signal III is assigned to compound 3. The lower field signal of III is assigned to the outer phosphorus atoms, which are trans to chlorides, and the higher field signal of III is assigned to the two trans inner phosphorus atoms of 3 . This assignment is done by comparison with compounds 2 and 1 in a similar environment.

When 2 is added to the $\mathrm{CDCl}_{3}$ solution of 3 , no additional signal appears, except that the relative intensity of signal II to III increases. The chemical shift of pure 2 in $\mathrm{CDCl}_{3}$ is also identical to that of signal II. Excess chloride ions has no effect on the chemical shift of 2 . The influence of chlorides and perchlorate anions on the chemical shift of $\left[\mathrm{Au}_{2}(\mathrm{dppm})_{2}\right]^{2+}$ was reported. ${ }^{4 \mathrm{C}} \mathrm{We}$, therefore, assign signal II to compound 2. The slight peak which appears at $\sim 27.6 \mathrm{ppm}$ can possibly be derived from compound 1 , but its nature is not certain.

${ }^{31} \mathrm{P}$ NMR spectrum of pure compound 1 in $\mathrm{CDCl}_{3}$ at room temperature appears at $23.5 \mathrm{ppm}$, which is $3.1 \mathrm{ppm}$ upfield relative to signal $\mathrm{I}$ in Figure 3a. However, when compound 1 is added to the $\mathrm{CDCl}_{3}$ solution of 3 at $283 \mathrm{~K}$, no additional signal appears, except that the relative intensity of signal I to II increases. We tentatively assign signal I to compound 1 . The large chemical shift difference between pure compound 1 in $\mathrm{CDCl}_{3}$ and 1 in the above mentioned solution can possibly be due to the influence of

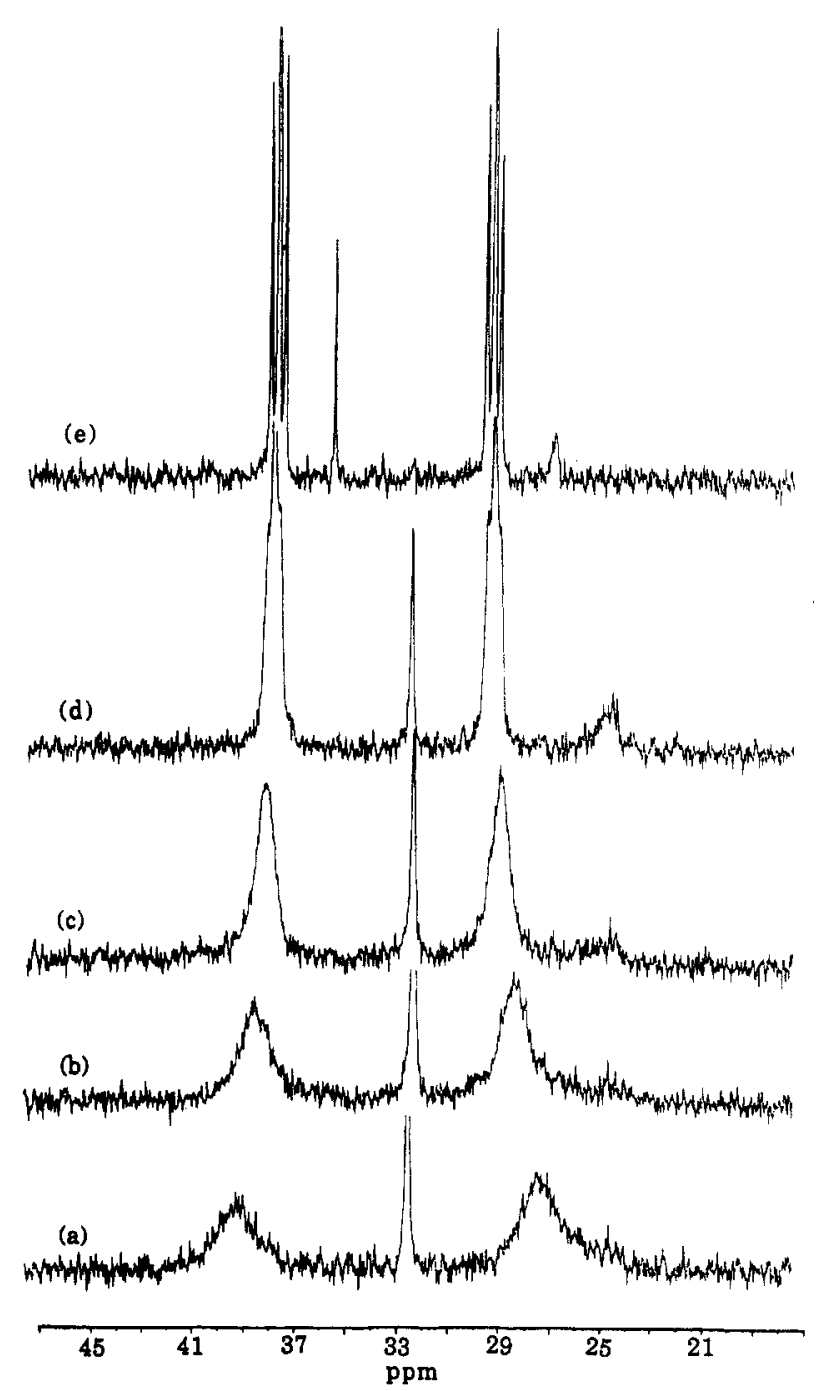

Figure 5. ${ }^{31} \mathrm{P}\left\{{ }^{1} \mathrm{H}\right\}$ NMR spectra of compound 3 in $\mathrm{CDCl}_{3}$ at $297 \mathrm{~K}$, with various molar ratios of 3 to $\mathrm{AgBF}_{4}$ : (a) no $\mathrm{AgBF}_{4}$; (b) $1: 0.25$; (c) 1:0.50; (d) $1: 1.00 ;$ (e) $1: 1.20$.

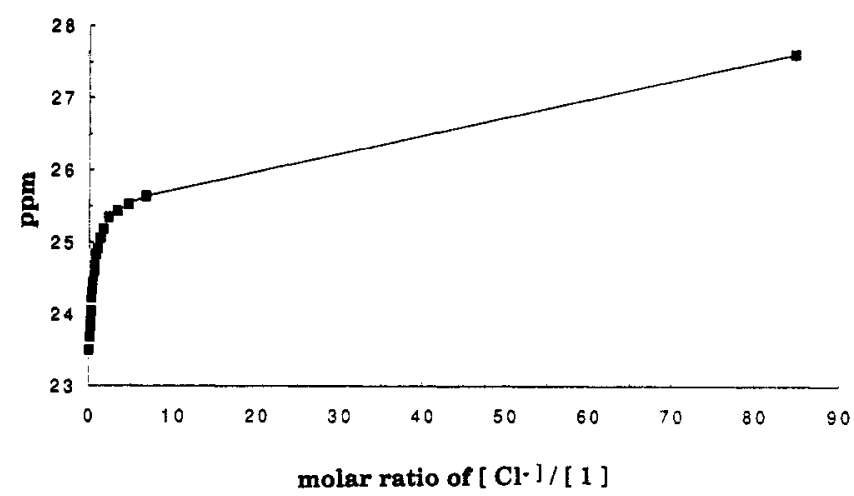

Figure 6. Change of chemical shift of Au2(dppm)Cl2 (8 mg, $9.42 \times 10^{-3}$ mmol in $400 \mathrm{~mL}$ of $\mathrm{CDCl}_{3}$ ) with each increment of $0.64 \times 10^{-3} \mathrm{mmol}$ of $n-\mathrm{Bu}_{4} \mathrm{NCl}$ in $10 \mathrm{~mL}$ of $\mathrm{CDCl}_{3}$.

the free halide ion. In order to support our proposal, the chemical shifts of compound 1 under various amounts of chloride ions are determined. Indeed, the chemical shift of compound 1 moves gradually downfield upon addition of $(n-\mathrm{Bu})_{4} \mathrm{NCl}$ (Figure 6). The relationship, however, is not linear. The influence of the chloride ion on the chemical shift of 1 suggests that there is an interaction between 1 and the chloride anion. Interaction of halides with linear gold (I) compounds has been reported.4c,11

To further support our assignment, compound 1 and 2 is mixed (2:1 molar ratio) in $\mathrm{CDCl}_{3}$ at $297 \mathrm{~K}$. The ${ }^{31} \mathrm{P}$ NMR spectrum 


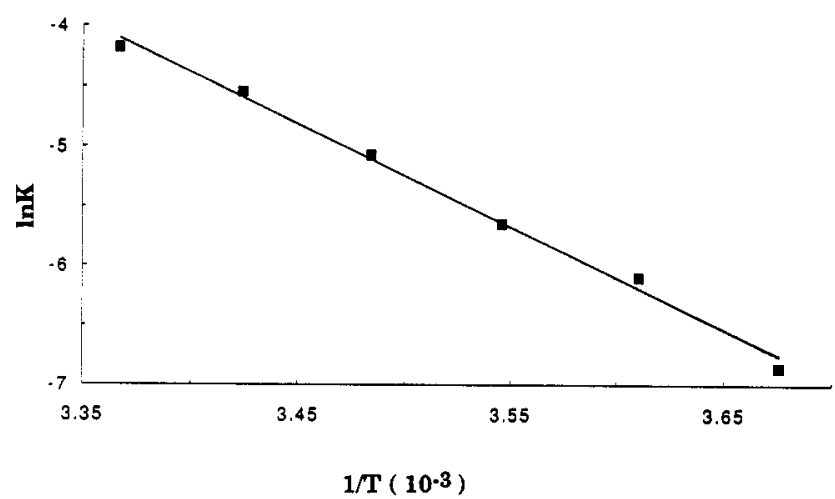

Figure 7. Plot of $\ln K$ verus $1 / T$ for the equilibrium between compounds 1,2 , and 3 in $\mathrm{CDCl}_{3}$.

shows signals identical to those of 3 dissolved in $\mathrm{CDCl}_{3}$. This is not true for a mixture of 1 and $\left[\mathrm{Au}_{2}(\mathrm{dppm})_{2}\right]\left(\mathrm{ClO}_{4}\right)_{2}$ which has no halide anions. Thus, while 3 in $\mathrm{CDCl}_{3}$ can be converted to compounds 1 and 2, compound 1 with compound 2 can also be reverted to compound 3 (eq. 1 ). It appears that compound 3 is in equilibrium with compounds 2 and 1 . Equilibrium constants in $\mathrm{CDCl}_{3}$ at various temperatures are measured $\left(K_{297}=1.33 \times\right.$ $10^{-3}, K_{292}=9.24 \times 10^{-4}, K_{287}=5.46 \times 10^{-4}, K_{282}=3.06 \times 10^{-4}$, $K_{277}=1.95 \times 10^{-4}, K_{272}=9.10 \times 10^{-5}$ ). A plot of $\ln K$ versus $1 / T$ gave a straight line (Figure 7). Using the Gibbs free energy equation, $\Delta H^{\circ}(80.89 \pm 2.63 \mathrm{~kJ} / \mathrm{mol})$ and $\Delta S^{\circ}(222.86 \pm 0.68$ $\mathrm{J} /(\mathrm{mol} \cdot \mathrm{K})$ are obtained. These values are consistent with our observation that, at low temperature, equilibrium favors the formation of 3. The variation of the spectral intensity upon gradual addition of $\mathrm{AgBF}_{4}$ in Figure 4 can also be explained by the equilibrium. Among the three compounds, 3 will be the first compound to have its $\mathrm{Cl}^{-}$removed by $\mathrm{AgBF}_{4}, 3$ is followed by 2 and then 1 , according to the strength of these $\mathrm{Au}-\mathrm{Cl}$ bonds. The equilibrium will shift the reaction of eq 1 toward the formation of 3 to increase the concentration of $\mathrm{Cl}^{-}$. Therefore the amount of $\left[\mathrm{Au}_{3}(\mathrm{dppm})_{2} \mathrm{Cl}_{2}\right] \mathrm{BF}_{4}$ will gradually increase, while $\mathbf{2}$ and $\mathbf{1}$ will gradually decrease upon addition of $\mathrm{AgBF}_{4}$. Addition of chloride ion will shift the reaction of eq 1 toward the formation of 2 and 1.

$$
\begin{aligned}
& 2\left[\mathrm{Au}_{3}(\mathrm{dppm})_{2} \mathrm{Cl}_{2}\right] \mathrm{Cl} \rightleftharpoons \mathrm{Au}_{2}(\mathrm{dppm})_{2} \mathrm{Cl}_{2}+ \\
& 2 \mathrm{Au}_{2}(\mathrm{dppm}) \mathrm{Cl}_{2}
\end{aligned}
$$

Apparently, the driving force for the instability of $\mathbf{3}$ in solution is the reaction of chloride anion with the trinuclear gold compound. The weakly bonded chloride anion in $\mathbf{2}$ is also responsible for the reaction of 1 and 2 to yield 3. A plausible pathway for these interconversion is shown in Scheme 1 . While each of the noncentral gold atom bonds to a neutral phosphine and an anionic chloride ligand, the central gold atom has two neutral phosphine ligands, suggesting that the central gold atom might bear more positive charge and hence be more susceptible to be attacked by a nucleophile. The longer central Au1-P2 bond length and the shorter noncentral Au2-P1 bond length also suggest that the central Au1-P2 bond may be more reactive than the noncentral Au2-P1 bond. An attack of a chloride anion on the central gold atom will produce compound 1 and $\mathrm{Au}(\mathrm{dppm}) \mathrm{Cl}$. Combining two molecules of $\mathrm{Au}(\mathrm{dppm}) \mathrm{Cl}$ will generate 2 through several steps. The equilibrium between $\mathrm{Au}(\mathrm{dppm}) \mathrm{Cl}$ and 2 was proposed. ${ }^{11 c}$ Thus, while compound 1 can be produced directly from 3 , compound 2 requires at least two more steps to be formed. These reactions are all reversible. Therefore, one should expect that the interconversion rate between compound $\mathbf{3}$ and $\mathbf{1}$ is faster

(11) (a) Jaw, H.-R.; Savas, M. M.; Rogers, R. D.; Mason, W. R. Inorg. Chem. 1989, 28, 1028. (b) Shain, J.; Fackler, J. P., Jr. Inorg. Chim. Acto 1987, 131, 157. (c) Berners-Price, S. J.; Sadler, P. J. Inorg. Chem. 1986, 25,3822 .
Scheme 1

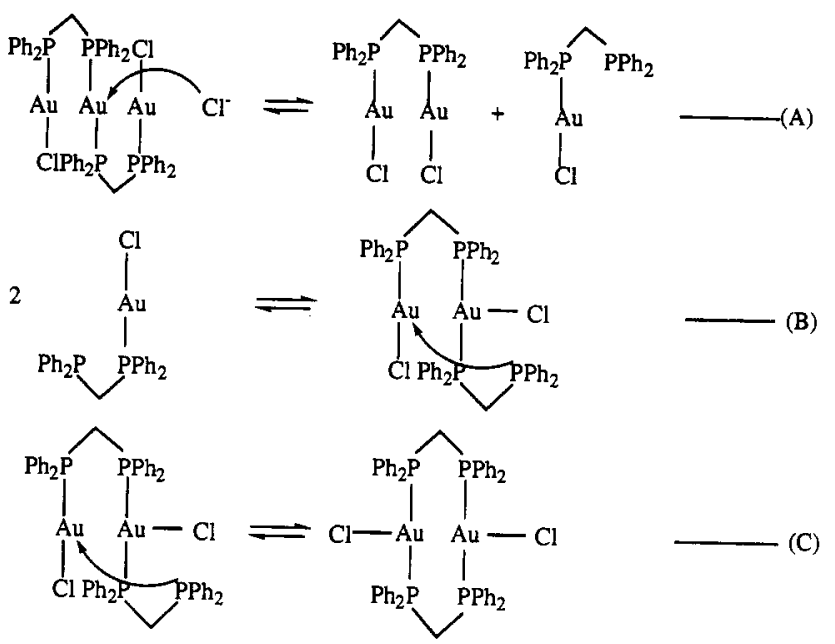

than that between compound 3 and 2 . This argument is consistent with our observation that signals I and III merge before signals II and III, and the exchange rates depend on the concentration of chloride ion. The spectral change of 3 upon addition of $\mathrm{AgBF}_{4}$, and the spectral changes of $\left[\mathrm{Au}_{3}(\mathrm{dppm})_{2} \mathrm{Cl}_{2}\right] \mathrm{BF}_{4}$ upon addition of $\mathrm{Cl}^{-}$are also consistent with the proposed scheme. DMSO, which has a much higher dielectric constant (45) than chloroform $(4.8),{ }^{12}$ has better ability to separate ions. This mechanism also explains the slower exchange rates in DMSO.

In conclusion, we have demonstrated that the instability of 3 in solution is due to the presence of the free chloride anion. In solution, 3 equilibrates with 1 and 2 ; therefore, the characterization of 3 in solution is difficult. This is the reason why that 3 has not been reported. The possible isolation of 3 in this work is due to the proper choice of solvent, such that both the equilibrium and the solubility favor its isolation.

\section{Experimental Section}

${ }^{31} \mathrm{P}\left\{{ }^{1} \mathrm{H}\right\}$ NMR spectra were recorded on a Brüker AC-F300 spectrometer (at $121.5 \mathrm{M} \mathrm{Hz}$ ). Chemical shifts are reported relative to an external standard $85 \% \mathrm{H}_{3} \mathrm{PO}_{4}$, with downfield shifts being positive. Spectral simulation of the $\mathrm{AA}^{\prime} \mathrm{BB}^{\prime}$ pattern was done by the PANIC of Brüker. Room-temperature solid emission spectrum was record on a Aminco-Bowman luminescence spectrometer. Emission lifetime were measured by using an Edinburgh Analytical Instruments CD900 spectrometer. Microanalyses were performed by Taiwan Instrumentation Center. $\mathrm{HAuCl}_{4} \cdot 4 \mathrm{H}_{2} \mathrm{O}$ was purchased from Kanto Chemicals. Dppm was purchased from Strem Chemicals. 2,2'-Thiodiethanol (thiodiglycol, $\left(\mathrm{HOCH}_{2} \mathrm{CH}_{2}\right)_{2} \mathrm{~S}$ ) was purchased from Riedel-deHaęn Laboratory Chemicals.

The equilibrium constants at different temperatures were obtained as described below. $\left[\mathrm{Au}_{3}(\mathrm{dppm})_{2} \mathrm{Cl}_{2}\right] \mathrm{Cl}\left(32.0 \mathrm{mg}, 2.18 \times 10^{-2} \mathrm{mmol}\right)$ was dissolved in $\mathrm{CDCl}_{3}(250 \mathrm{~mL})$. ${ }^{31} \mathrm{P}$ NMR spectra of the sample were taken at $297,292,287,282,277$, and $272 \mathrm{~K}$. The concentrations of compounds 1,2 , and 3 were calculated by the integrations of the individual signal. The equilibrium constants, $K$, were calculated by the following equation:

$$
K=\frac{\left[\mathrm{Au}_{2}(\mathrm{dppm})_{2} \mathrm{Cl}_{2}\right]\left[\mathrm{Au}_{2}(\mathrm{dppm}) \mathrm{Cl}_{2}\right]^{2}}{\left[\mathrm{Au}_{3}(\mathrm{dppm})_{2} \mathrm{Cl}_{2}\right]^{2}[\mathrm{Cl}]^{2}}
$$

This equation produced the best linear fit of $\ln K$ versus $1 / T$. However, this was not the case for the $K$ values obtained in DMSO; presumably, partial dissociation of chloride in compound 2 occurred.

$\mathrm{Au}_{2}(\mathrm{dppm}) \mathrm{Cl}_{2}$ (1). This compound can be prepared by the method reported by Schmidbaur ${ }^{2}$ or by the following two different methods: (a)

(12) Huheey, J. E. Inorganic Chemistry, 3rd ed.; Harper \& Row: New York, $1983, \mathrm{p} 340$

(13) Gabe, E. J.; Le page, Y.; Charland, J.-P.; Lee, F. L.; White, P. S. J. Appl. Crystallogr. 1989, 22, 384. 
$\mathrm{HAuCl}_{4} \cdot 4 \mathrm{H}_{2} \mathrm{O}(313 \mathrm{mg}, 0.76 \mathrm{mmol})$ in EtOH $(20 \mathrm{~mL})$ was mixed with dppm ( $300 \mathrm{mg}, 0.78 \mathrm{mmol}$ ) in $\mathrm{CH}_{2} \mathrm{Cl}_{2}(20 \mathrm{~mL}$ ). After the suspended solution was stirred for $30 \mathrm{~min}$., $\mathrm{CHCl}_{3}(20 \mathrm{~mL})$ was added, and was stirred for another hour. The colorless resuitant solution was set aside until the volume was reduced to $\sim 20 \mathrm{~mL}$, at which time, large colorless crystals were formed. This was filtered and dried in air. The yield was $93 \%$. (b) $2,2^{\prime}$-Thiodiethanol $\left(0.2 \mathrm{~mL}\right.$, excess) was added to $\mathrm{HAuCl}_{4} \cdot 4 \mathrm{H}_{2} \mathrm{O}$ (121 $\mathrm{mg}, 0.294 \mathrm{mmol})$ in EtOH $(10 \mathrm{~mL})$, and the mixture was stirred at $40^{\circ} \mathrm{C}$ for $40 \mathrm{~min}$ at which time the yellow solution became colorless. To this resultant solution dppm ( $56 \mathrm{mg}, 0.147 \mathrm{mmol}$ ) in $\mathrm{CH}_{2} \mathrm{Cl}_{2}(10 \mathrm{~mL}$ ) was added. After stirring for an additional $1 \mathrm{~h}$, the white precipitates were filtered and then recrystallized from $\mathrm{CH}_{2} \mathrm{Cl}_{2}$. Large colorless crystals were obtained in $85 \%$ yield. The identification of this compound was confirmed by EA, FAB/MS, mp, and single-crystal X-ray diffraction.

$\mathrm{Au}_{2}(\mathrm{dppm})_{2} \mathrm{Cl}_{2}(2)$. This compound can be prepared by the method reported by Schmidbaur ${ }^{3}$ or by the following method: dppm ( $461 \mathrm{mg}$, $1.20 \mathrm{mmol}$ ) in $\mathrm{CH}_{2} \mathrm{Cl}_{2}(20 \mathrm{~mL})$ was added to $\mathrm{HAuCl}_{4} \cdot 4 \mathrm{H}_{2} \mathrm{O}(313 \mathrm{mg}$, $0.76 \mathrm{mmol})$ in EtOH $(20 \mathrm{~mL})$. This solution was stirred for $30 \mathrm{~min}$, and then $\mathrm{CHCl}_{3}(20 \mathrm{~mL})$ was added and the mixture was stirred for another $30 \mathrm{~min}$. The resultant solution was dried under vacuum. The residue was then recrystallized from ethyl ester. Colorless crystals were collected in $\sim 80-90 \%$ yield. This compound was identified by mp and $\mathrm{EA}$. The corresponding $\left[\mathrm{Au}_{2}(\mathrm{dppm})_{2}\right]\left(\mathrm{ClO}_{4}\right)_{2}$ was prepared by the literature method. $4 c, 7$

$\left[\mathrm{Au}_{3}(\mathrm{dppm})_{2} \mathrm{Cl}_{2}\right] \mathrm{Cl} \cdot \mathrm{EtOH} \cdot \mathrm{H}_{2} \mathrm{O}\left(3 \cdot \mathrm{H}_{2} \mathrm{O}\right)$. This compound was prepared by two different methods: (a) Solid dppm ( $384 \mathrm{mg}, 1.00 \mathrm{mmol}$ ) was added to $\mathrm{HAuCl}_{4} 4 \mathrm{H}_{2} \mathrm{O}(330 \mathrm{mg}, 0.80 \mathrm{mmol})$ in EtOH $(50 \mathrm{~mL})$. This suspended solution was stirred for $30 \mathrm{~min}$, during which time the color changed from a deep yellow to a light yellow. The solvent was then dried completely with a rotary evaporator, and the solid was washed several times with ethyl ether. The residue was dissolved in ethyl acetate or acetone together with a few drops of ethanol and was allowed to evaporate slowly. Large colorless crystals were obtained in $61 \%$ yield. (b) $\mathrm{HAuCl}, 4 \mathrm{H}_{2} \mathrm{O}(93 \mathrm{mg}, 0.226 \mathrm{mmol})$ in $\mathrm{EtOH}(10 \mathrm{~mL})$ was added to an excess of $2,2^{\prime}$-thiodiethanol $(0.2 \mathrm{~mL})$ and was stirred at $40^{\circ} \mathrm{C}$ for $40 \mathrm{~min}$. To this resultant colorless solution was added dppm ( $58 \mathrm{mg}, 0.151 \mathrm{mmol})$ in $\mathrm{CH}_{2} \mathrm{Cl}_{2}(10 \mathrm{~mL})$. After being stirred for another hour, the solution evaporated to an oily liquid. Upon addition of ether $(10 \mathrm{~mL})$ to this oily liquid, white crystals precipitated. This white solid was filtered and redissolved in a minimum amount of acetone or ethyl acetate together with a few drops of ethanol. Large colorless crystals were collected after the solvent was allowed to evaporate slowly to half of its volume. The yield was $60 \%$. The purity of this compound can be checked with a portable UV lamp. The compound showed a greenish blue emission. Mp: 205-206 ${ }^{\circ} \mathrm{C}$. Anal. Calcd for $\mathrm{C}_{52} \mathrm{H}_{50} \mathrm{Cl}_{3} \mathrm{OP} \mathrm{Au}_{3}: \mathrm{C}, 41.3 ; \mathrm{H}, 3.3$. Found: C, 41.7; H, 3.2.

$\mathrm{X}$-ray Diffraction of 3. Suitable crystals were chosen to do the singlecrystal structure determinations. A crystal of 3.EtOH was obtained as described in the preparation method. Compound 3.EtOH. $\mathrm{H}_{2} \mathrm{O}$ was obtained from the crystallization of 3 in ethanol solution. The X-ray diffraction data were measured on a four-circle diffractometer. Intensities of three standard reflections were monitored every hour throughout the data measurement. The variation was less than $2 \%$. The other essential details of single-crystal data measurement and refinement are given in Table 1.

Acknowledgment. This work was supported by the National Science Council of Taiwan, NSC82-0618-M-030-013.

Supplementary Material Available: Tables giving complete positional and isotropic thermal parameters, anisotropic themal parameters, and bond distances and angles and an ORTEP drawing of 3.EtOH with complete labels (4 pages). Ordering information is given on any current masthead page. 